\title{
Publicidad en la política, política en la publicidad
}

\author{
Francesco SCRETI $^{1}$ \\ Universidade da Coruña
}

\begin{abstract}
RESUMEN:
En este artículo analizo seis ejemplos distintos por épocas y procedencia sociocultural de mezclas entre la publicidad y la política. Tres casos en los que tres sujetos políticos (Zapatero, ABC, Partido Comunista Italiano) emplean la publicidad en sus discursos políticos para alcanzar sus fines socio-discursivos, y tres casos en los que tres sujetos comerciales (Quilmes, Axe, M\&M's) emplean la política en sus discursos publicitarios para alcanzar sus fines socio-discursivos. Mediante el análisis de estos seis casos pretendo demostrar que, aunque tengan lugar «préstamos cruzados» entre estos dos dominios semióticos y sociales, la relación entre la política y la publicidad está lejos de ser simétrica, siendo el publicitario un discurso totalizante, que fagocita el discurso político, como muchos otros, banalizándolo.
\end{abstract}

PALABRAS CLAVE: propaganda; propaganda política; publicidad política; publicidad; propaganda comercial; publicidad comercial.

TITLE: Advertising in politics, politics in advertising.

\begin{abstract}
In this paper I will analyze six cases of mix between politics and advertising. In the first three examples three political subjects (Zapatero, ABC, Partido Comunista Italiano) employs advertising in their political discourse in order to achieve their social and discursive ends. In the last three examples, three commercial subjects (Quilmes, Axe, M\&M's) employs politics in their commercial discourse in order to achieve their social and discursive ends. Through the analysis of these six cases, I will show that, even if reciprocal borrowings exist between these two semiotic and social domains, the relation between Politics and Advertising is not symmetrical. Actually the advertising discourse phagocytes political discourse (as many other ones), banalizing it.
\end{abstract}

KEY WORDS: propaganda; political propaganda; political advertising; advertising; commercial propaganda; commercial advertising.

\section{Introducción}

A menudo en la literatura sobre política y publicidad se ha analizado cómo la primera se haya servido de la segunda para alcanzar sus fines discursivos y sociales ${ }^{2}$. Los casos en los que ha acontecido lo contrario han sido estudiados en menor medida.

Aun así, en referencia a estos últimos casos, algunos han hablado de «préstamos cruzados» entre estos dos dominios sociales y discursivos, entre los universos sociosemióticos de la publicidad y de la política: por ejemplo la revista francesa Mots. Les

1 Profesor de italiano en el Centro de Linguas de la Universidade da Coruña y doctorando en Lingüística Aplicada. E-mail francesco.screti@hotmail.it web personal: www.francescoscreti.eu

2 Aquí considero la política y el discurso político como el discurso de las instituciones políticas o ligadas a la política relacionado al ejercicio del poder político o de las relaciones políticas. 
langages du politique, en el número «Publicité et politique. Emprunts croisés», en prensa. La expresión «préstamos cruzados» parece sugerir la idea de que la relación entre la política y la publicidad es recíproca. Es decir, que la publicidad toma prestados modos, técnicas y palabras de la política, al menos en la misma medida en que la política toma prestados modos, técnicas y lenguajes de la publicidad. Este último caso de préstamo es sin duda el más claro; hay más acuerdo al respecto y desde luego también más literatura. El caso del préstamo por parte de la publicidad de temas, técnicas, palabras, personas/personajes, lenguajes y modos de la política es menos claro y más problemático y ha sido estudiado menos. De ello trataré en este artículo desde una perspectiva crítica, que desafiará la definición de reciprocidad de los préstamos entre estos dos espacios sociosemióticos.

En él analizaré 6 casos, de épocas y contextos socioculturales distintos, pero que constituyen todos ejemplos de «préstamos cruzados» entre la política y la publicidad. En el primer apartado analizaré tres casos de préstamos hechos por la política de técnicas y recursos de la publicidad o de citas publicitarias hechas por sujetos políticos. El primer ejemplo concierne la campaña electoral de José Luis Rodríguez Zapatero en 2008. El segundo ejemplo es una viñeta del diario ABC, en la que se representa a Zapatero como protagonista del anuncio de un banco (ING Direct) actualmente televisado en España. El tercero es un cartel del Partido Comunista Italiano (PCI) de 1953 en el que se cita una marca comercial.

En el segundo apartado analizaré tres casos de préstamos hechos por la publicidad de técnicas, recursos, formas y lenguajes de la política. El primer ejemplo procede de Argentina, se trata del anuncio de la cerveza Quilmes de 2007, que tiene la forma de un discurso enunciado por un político en un mitin, aunque con características un tanto peculiares. El segundo ejemplo procede de EEUU y constituye un caso más específico, en el que se emplea explícitamente -y sin permiso- la imagen (en sentido estricto, pero también metafórico) de un político para publicitar un producto: se trata de la campaña de marketing viral del desodorante Axe. El tercero procede de Australia y constituye un caso aún más peculiar, en cuanto se escenifica una campaña electoral en toda regla, con candidatos, urnas, elecciones, mítines, papeletas, spot, posters, etc. para promocionar los caramelos M\&M's.

\section{Metodología}

La metodología empleada es ampliamente multidisciplinar. Lo es en primer lugar porque no empleo uno sólo sino muchos instrumentos analíticos, procedentes de diversas disciplinas, pero que pueden funcionar conjuntamente para ilustrar la tesis de este artículo. En segundo lugar es multidisciplinar porque los mismos objetos son analizados mediante diferentes herramientas. Técnicas y herramientas de la lingüística, espe- 
cialmente de la pragmática ${ }^{3}$ y de la semiótica ${ }^{4}$ se intersecan con las de la retórica ${ }^{5}$, las ciencias de la comunicación y la psicología social ${ }^{6}$. Quizá esta elección más que multi/trans/interdisciplinaria podría parecer «indisciplinada», como también Morin provocativamente lo advierte ${ }^{7}$. Pero no tener un método -o tener uno hecho de muchos- es en sí un método y es el único que me parece que permita acercarse a la comprensión de un fenómeno complejo como es el discurso persuasivo. Todos los fenómenos se analizan bajo una perspectiva general crítica ${ }^{8}$, deudora del Análisis Crítico del Discurso ${ }^{9}$ La perspectiva es crítica en el sentido de que no acepta la realidad como reducción empirista, sino que la ve como un campo de posibilidades alternativas y que desvela las ideologías y los intereses de los agentes/actores comunicativos. El Análisis Crítico del Discurso permite analizar críticamente el discurso (entendido lato sensu como un texto -escrito oral visual o, como más frecuentemente ocurre, multimodal- actualizado en situaciones comunicativas concretas) como acción social estructurante, y lo hace con una atención especial al contexto comunicativo situacional e histórico y a la intertextualización, esto es, el hecho de que los discursos sean «discursos de discursos».

En relación a la muestra analizada en este trabajo, soy consciente de que la decisión de trabajar con unos materiales tan dispares más que con una muestra homogénea y representativa de la producción publicitaria en el campo de la comunicación política constituye una debilidad, pero la consideración de diversos textos transmitidos mediante diversos soportes y nacidos/intercambiados en diferentes momentos históricos o contextos socioculturales pretende simplemente trazar una primera (y no definitiva) aproximación a la evolución experimentada en este ámbito. La muestra no es orgánica,

3 Levinson, S. (1989): Pragmática, Barcelona, Teide; WiLSON, J. (1990): Politically Speaking, Oxford, Blackwell, cap. 3.

4 HALl, S. (2007): Esto significa esto, esto significa aquello. Semiótica: guía de los signos y su significado, Barcelona, Blume; BEuchot, M. (2004): La semiótica. Teorías del signo y el lenguaje en la historia, México, Fondo de cultura económica; CAPretTini, G. P. (1997): Segni, testi, comunicazione. Gli strumenti semiotici, Turín, Utet.

5 ARISTÓTELES (1985): Retórica, (ed.) A. Tovar, Madrid, Centro de Estudios Constitucionales; ALbaladejo Mayordomo, T. (1989): Retórica, Madrid, Síntesis; FerRaz Martínez, A. (1993): El lenguaje de la publicidad, Madrid, Arco Libros.

6 Hewstone, M., W. Stroebe, et AL. (1998): Manuale di psicologia sociale, Bolonia, Il Mulino; PRATKANIS, A. y E. ARONSON (1994): La era de la propaganda. Uso y abuso de la persuasión, Barcelona, Paidós; PETTY, R. y CACIOPPO, J. T. (1986a): «the elaboration likelihood model of persuasion», en L. BERKOWITZ (comp.), Advances in experimental social Psychology (vol. 19,), New York, Academic Press, 123-205; PETTY R. y CACIOPPO, J. T. (1986b): Communication and persuasion; central and peripheral routes to attitude change, New York, Springer-Verlag.

7 MORIN, E. (2005): Introducción al pensamiento complejo, Barcelona, Gedisa, 79.

8 PignotTi, L. (1976): La super-nada. Ideología y lenguaje de la publicidad, Valencia, Fernando Torres; MARCUSE, H. (1968): El hombre unidimensional, ensayo sobre la ideología de la sociedad industrial avanzada, Barcelona, Seix Barral.

9 Por ejemplo, WodAK, R. y M. MEYER (2001): Methods of critical discourse analysis, Londres, SAGE; FAIRCLOUGH, N. (2001): «Critical discourse analysis as a method in social scientific research», en WODAK, R. y M. MEYER (eds.) (2001: 122-138); VAN DIJK, T.A. (2001): «Multidisciplinary CDA: a plea for diversity», en WODAK, R. y M. MEYER (eds.) (2001: 95-120). 
sino que los anuncios analizados han sido seleccionados expresamente de forma que pertenecieran a diversos períodos y a diversos países, a diversas culturas. En realidad hubiera podido añadir un número mucho mayor de ejemplos, como el caso de los anuncios gráficos (pósters) de la franquicia de cafeterías norteamericana Dunkin Coffee (Fig. 1) o, siempre en ámbito español, el caso de los spot televisivos españoles del fabricante de muebles sueco IKEA (Fig. 2).

Fig. 1 El doble de Zapatero en los pósters de Dunkin Coffee
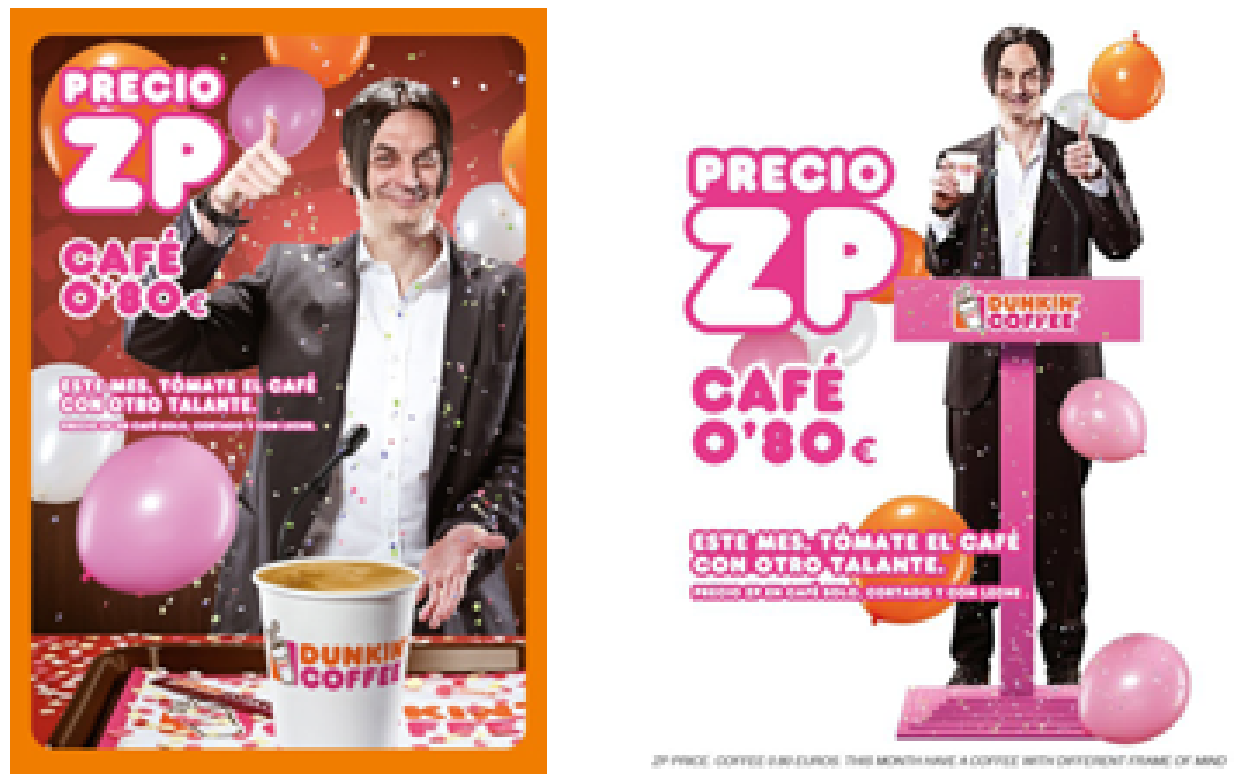

El anuncio gráfico de Dunkin Coffee «Precio ZP. Café a 80 céntimos» de enero de 2010 y firmado por la agencia JWT España utilizaba un doble del Presidente del Gobierno José Luis Rodríguez Zapatero, para presentar la oferta del grupo, un café por $0.80 €$, bajo el eslogan «Precio ZP. Café a 80 céntimos. Tómate un café con otro talante». El anuncio retoma por un lado una polémica nacida tras la respuesta del Presidente Zapatero a la pregunta de un ciudadano -intencionado a mostrar la distancia de los políticos de la vida real- sobre el precio de un cafe ${ }^{10}$ y por otro lado dos términos y dos topoi de los empleados en la construcción de la imagen de Zapatero: el famoso logotipo ZP y la palabra "talante".

10 En el programa Tengo una pregunta para Vd. de Radio Televisión Española del 28 de marzo de 2007, a un año vista de las elecciones generales españolas, el Presidente Zapatero, preguntado por un ciudadano sobre el precio de un café, respondió «80 céntimos (de euro)», demostrando, como pretendía el ciudadano, una subestimación del coste de la vida y un escaso conocimiento de los problemas diarios de la gente común. 
Fig. 2 Captura del final del spot «Tengo derecho a mi fiesta» de IKEA

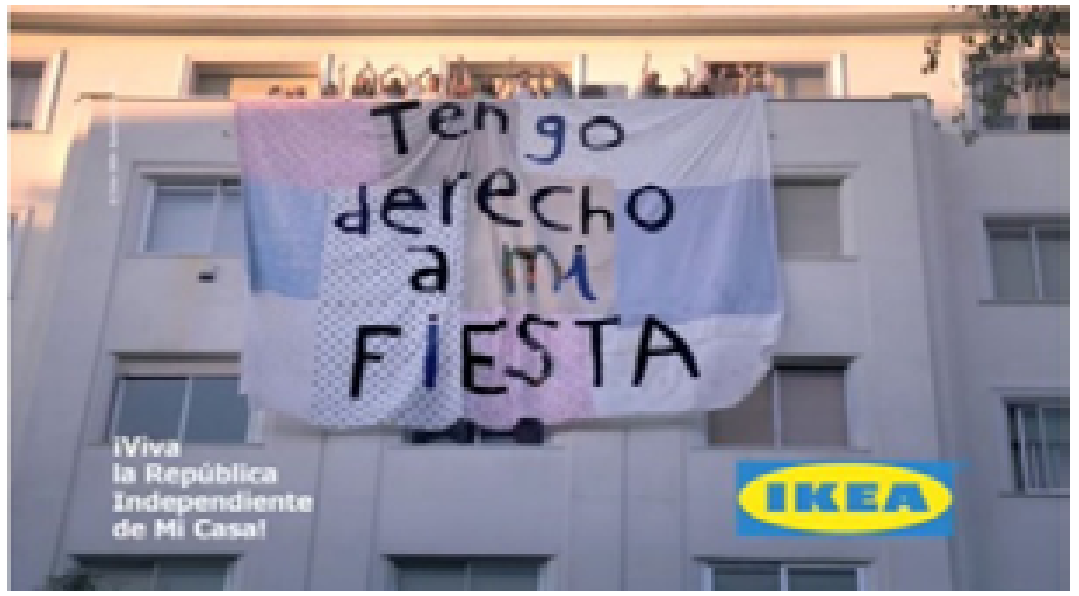

La campaña para IKEA España con el conocido concept «la república independiente de mi casa», declinado luego en distintos eslóganes como variaciones del tema ${ }^{11}$, nace en abril de 2006 a manos de la agencia de publicidad española *S, C, P, F... El concept y los varios eslóganes tenían especial relevancia e interés en cuanto caían en el 75 aniversario de la proclamación de la II República española (1931-36) a la cual en cierto modo hacen referencia. También otros aspectos del anuncio se referían al dominio de la política, por ejemplo los deseos de cada protagonista del vídeo eran proclamados como consignas políticas o como artículos de una carta constitucional, etc. la relevancia del anuncio es pues máxima en un país, como España, donde monárquicos y republicanos luchan desde hace dos siglos. La originalidad del anuncio (concept y eslogan) justifica su longevidad. El anuncio «Tengo derecho a mi fiesta», nacido en julio de 2011 y firmado por la misma agencia *S,C,P,F..., prosigue el concept de la primera campaña y sigue jugando con lemas y temas de la política, además de aprovecharse de la coyuntura política actual y de su relevancia comunicativa y mediática; esta nueva campaña, que reivindica el optimismo y la diversión en un momento de grave crisis económica, cae en el 80 aniversario de la II República; pero sobre todo, la reivindicación de un derecho, que, como en las campañas anteriores, procede de personas corrientes, recuerda las protestas de los movimientos ciudadanos espontáneos del $15 \mathrm{M}$ y de los indignados, nacidos el 15 de mayo del 2011 en España y que han recibido amplísimas coberturas informativas.

11 Como se puede observar por ejemplo de los catálogos de la empresa, en 2007 y 2008 el eslogan era «bienvenido a la república independiente de tu casa»; en 2007 también se empezó a comercializar un felpudo con el eslogan «bienvenido a la república independiente de mi casa»; en 2009 el eslogan pasó a ser «tu casa, tu reino, bienvenido a la república independiente de tu casa»; en 2010 y 2011 el eslogan es «viva la república independiente de mi casa». 
Incluso limitándose a los casos españoles, los ejemplos podrían ser muchos más, pero he creído suficiente para demostrar las hipótesis de fondo de este artículo, limitarme a los pocos ejemplos incluidos aquí, variados por procedencia geográfica, histórica y cultural.

\section{Los datos}

\subsection{La política usa la publicidad}

Es de sobra conocida la utilización de técnicas publicitarias por parte de los partidos políticos para la elección de sus candidatos ${ }^{12}$. Es bajo esta perspectiva que debe verse, por ejemplo, entre otros fenómenos, el papel creciente de las imágenes en la comunicación política ${ }^{13}$ o el carácter progresivamente persuasivo más que argumentativo del discurso político actual ${ }^{14}$. Cabe aquí aclarar una cosa. En realidad el discurso políticoexactamente como el publicitario- siempre es persuasivo y argumentativo: está finalizado a convencer, presentando argumentos. Otra cosa es que los argumentos sean racionales (basados en el logos) o emotivos (basados en el pathos). En efecto, lo que ha pasado es que el discurso político a lo largo del tiempo ha ido reduciendo la centralidad de la argumentación lógico-racional en favor de argumentos emotivo-afectivos ${ }^{15}$.

Aunque algunos establezcan como fecha el $1952^{16}$, en mi opinión estos comienzos se pueden retrodatar de al menos 30 años, situándolos en la era de los fascismos, que coinciden con la masificación de la política y de la cultura en general, pero quizás incluso algunos años antes, con el comienzo de la sociedad de consumo de masas, esto es, con la masificación de la producción/consumo de bienes. Este paso del discurso

12 Albouy, S. (1994): Marketing et communication politique, Paris, L'Harmattan; REY, J. (coord.) (1999): «Comunicación política electoral. Elecciones municipales de Sevilla en 1999», Questiones publicitarias/Monografias, 2, Sevilla, Maecei; REY, J. (ed.) (2005): Propaganda electoral. Elementos publicitarios y estrategias comunicativas en las elecciones municipales de Sevilla en 2003, Sevilla, Maecei; RODRÍGUEZ ESCANCIANO, I. (2004): «la desarticulación de las estrategias electorales audiovisuales frente a la conmoción del 11-M», Área Abierta, 8; Rodríguez EsCANCIANO, I. y M. HernáNDEZ HerRarTe (2010): Lenguaje no verbal. Cómo gestionar una comunicación de éxito, Oleiros, Netbiblio.

13 Albouy (1994), op. cit., 225.

14 AdAm J. M. y BONHOMME M. (1997): L'argumentation publicitaire. Rhétorique de l'éloge et de la passion, Paris, Armand Colin, 19.

15 PratKanis, A. y E. ArONSON (1994): op. cit. La distinción de los discursos en géneros (judicial, epidíctico, deliberativo) es de Aristóteles (1985): op. cit. AlbaladeJo MAYORDOMO (1989), op. cit., la retoma para distinguir componentes discursivos centrales y periféricos, afirmando que todo discurso retórico tiene un componente central y otros periféricos. Debo a él esta definición de la centralidad del pathos respecto del logos.

16 Por ejemplo PINEDA CACHERO, A. (2007): «Propaganda y publicidad comercial. Un principio diferenciador», Questiones Publicitarias, 1(12), 108; ORIOL COSTA, P. (2008): «Estrategias de comunicación en una campaña electoral», en ORIOL COSTA, P., Cómo ganar unas elecciones. Comunicación y movilización en las campañas electorales, Barcelona, Paidós, 5, indica la campaña electoral de Eisenhower en EE.UU. como la primera en la que la emoción supera la argumentación. 
político de la argumentación racional a la emotiva empieza con la masificación progresiva del electorado activo, es decir con la ampliación progresiva del derecho a voto en las sociedades industriales de masas ${ }^{17}$. Observando la propaganda política de los años '30 o '40 -tanto en regímenes democráticos como dictatoriales- se nota que en la argumentación de los discursos retóricos políticos - pero también en los publicitarios-se reducen progresivamente los argumentos lógico-racionales en favor de los argumentos emotivo-afectivos o irracionales. Paralelamente se reduce el uso de las palabras y se incrementa el uso de técnicas icónicas: logotipos, colores, imágenes, dibujos, motivos, etc. Todo esto empieza en paralelo en la propaganda comercial y en la propaganda política. A la entrada en la vida política de grandes masas de población antes excluidas de los procesos electorales no correspondió su educación. Entre los nuevos electores había muchos analfabetos, que además estaban expuestos a muchos mensajes persuasivos: este es, en efecto, el período de la explosión de la publicidad comercial. Para convencer a un público creciente, poco culto o analfabeto y con poco tiempo para analizar los mensajes, se privilegian progresivamente recorridos periféricos y heurísticos (emotivos) sobre los recorridos centrales, más racionales ${ }^{18}$. Ya en años más recientes, la reducción de las diferencias entre los candidatos -debido al triunfo casi ubicuo del capitalismo y a la derrota de las alternativas imaginadas hasta ahora- ha favorecido aún más la marketingización de la política y la difusión de una persuasión basada sobre el pathos más que sobre el logos ${ }^{19}$.

En este apartado analizaré brevemente tres ejemplos de cómo la política se ha servido o se sirve de la publicidad para conseguir los votos.

\subsubsection{La campaña electoral de Zapatero en 2004 y 2008}

Este primer ejemplo es, al menos dentro de las fronteras españolas, ya clásico. Es un tema que cuenta con una amplísima literatura y que para los fines de este artículo no me parece necesite ser profundizado ${ }^{20}$. Aquí, para demostrar cómo la política tome prestados a la publicidad categorías, palabras, conceptos y técnicas, me referiré al hecho notorio de que los políticos cuentan con agencias de publicidad para sus campañas electorales $^{21}$. Pero también a las reflexiones de Campmany, responsable de la campaña electoral del Partido Socialista Obrero Español (PSOE) en 2004, quien considera a

\footnotetext{
17 REY, J. (1999): op. cit., 20-27.

18 PratKanis, A. y E. Aronson (1996): op. cit; Petty, R. y A. CACiOPPo (1986a): op. cit.; PetTy, R. y A. CACIOPPO (1986b): op. cit.

19 REY, J. (1999): op. cit., 20-27.

20 Por ejemplo, SCRETI, F. (2009), «"Con ceta de zetapero": análisis semiótico de la imagen de marca de José Luis Rodríguez Zapatero para las elecciones generales españolas del 09 de marzo de 2008», Pensar la Publicidad, 3(2); SCRETI, F. (2011), «El ojo y la zeta: la propaganda electoral de José Luis Rodríguez Zapatero para las elecciones generales españolas de 2008», Cultura, Lenguaje y Representación, 9.

21 Por ejemplo, el PSOE contó en 2004 con los servicios de la agencia DDB, y en 2008 con los de la agencia Sra. Rushmore.
} 
Zapatero un producto o una marca ${ }^{22}$. Bajo esta perspectiva mercadotécnica y de branding hay que analizar la invención de la sigla «ZP» en las elecciones de 2004 (Fig. 3), convertida en un logotipo como JFK o IKE; y la invención de la «Z» en las elecciones de 2008. En estos últimos comicios, esa letra se volvería el verdadero logotipo-símbolo del candidato y del concepto de la campaña electoral entera. Como otros logotipos comerciales, este símbolo concentraba toda la atención de los receptores-electores sobre sí mismo y sobre el candidato-producto al que resumía. La «Z» resumía el nombre del candidato (por analogía con su inicial), su ideología y la de su partido (por el color rojo) y su forma de hablar (por ejemplo en la pronunciación zapateriana de prosperidaz). En efecto uno de los eslóganes de la campaña fue «con z de Zapatero» (Fig. 4).

Fig. 3 El logotipo ZP en la campaña electoral de 2004
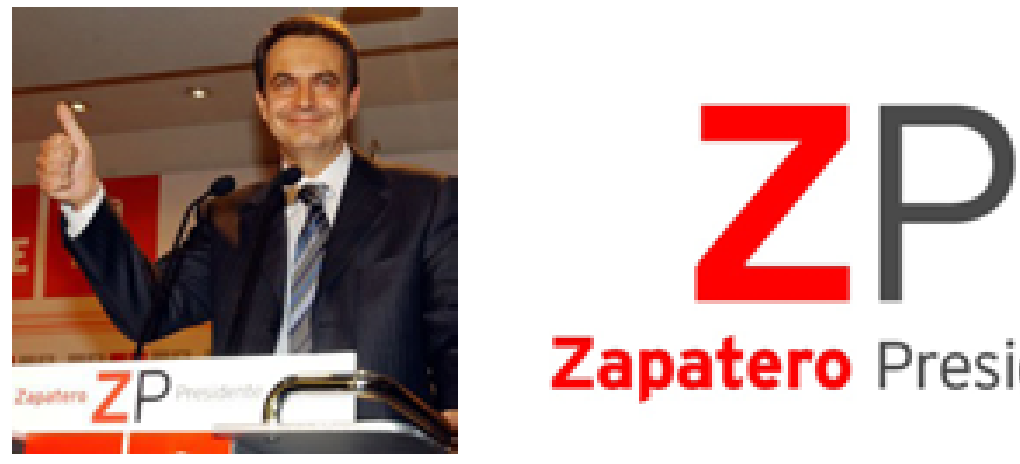

\section{Zapatero Presidente}

Fig. 4 La Z en la campaña electoral de 2008
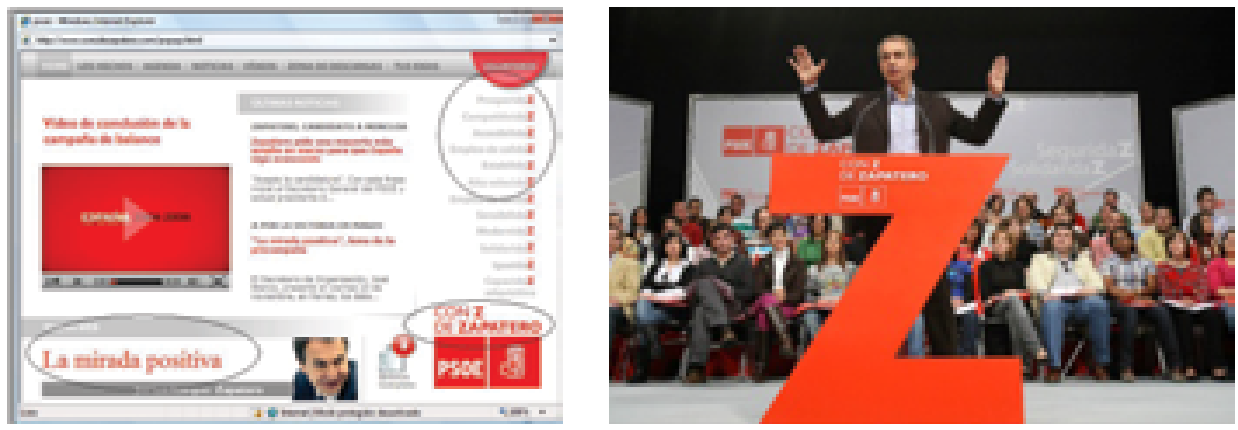

Las dos campañas del PSOE en 2004 y 2008 son dos ejemplos de persuasión emotivo-afectiva, piénsese, por ejemplo, en el eslogan «Defender la Alegría».

22 CAmpmany, J. (2005): El efecto ZP. 1000 días de campaña para llegar a la Moncloa, Barcelona, Planeta. 
El segundo tipo de uso de la publicidad por parte de la política es diferente y bastante más original. Se refiere al empleo de fórmulas o imágenes de la publicidad comercial por parte de los políticos o para hacer política. Un ejemplo de este último tipo puede ser la famosa frase pronunciada en junio de 2005 por el entonces Ministro del Interior francés Nicolas Sarkozy de «nettoyer au Kärcher [limpiar al Kärcher]» la banlieue [barriada] de La Courneuve llamada Cité des 4000, donde un niño de 11 años había muerto a consecuencia de los disparos recibidos accidentalmente durante un tiroteo, ocasionado por un ajuste de cuentas entre bandas rivales. Kärcher es la marca del mayor fabricante mundial de equipos de limpieza y no deja de ser ilustrativo el hecho de que un ministro use una metáfora basada sobre un producto comercial ${ }^{23}$.

Otro ejemplo es el que se analiza en el siguiente apartado ya en terreno español.

\subsubsection{El anuncio de ING Direct en ABC}

Analizaré aquí un ejemplo de cómo la política usa la publicidad para elaborar su discurso y alcanzar sus fines sociales y discursivos. Obviamente consideramos aquí al diario ABC, afín al Partido Popular (partido de oposición del PSOE actualmente al gobierno), como un sujeto político, en el sentido de que es capaz de crear discursos con amplias repercusiones políticas. Aquí el fin del discurso político de $\mathrm{ABC}$ es deslegitimar al Gobierno. La crítica se realiza citando un anuncio actualmente televisado en España. Este diario critica la política económica de Zapatero definiendo al presidente del Gobierno como una persona que ha causado el endeudamiento de España y de los españoles, por lo tanto un «endeudador», en el neologismo tan figurado de ABC. El intento es obviamente de persuadir al receptor sin argumentos racionales, sino mediante imágenes y figuras retóricas rápidamente comprensibles y fácilmente memorizables. Esto se hace mediante una viñeta, que se puede considerar un género de opinión, capaz de condensar en muy pocas palabras (o ninguna) muchos argumentos, gracias sobre todo, al poder de la imagen. La viñeta está representada en la Fig. 5. y está claramente inspirada en los últimos anuncios del banco ING Direct.

Merece la pena en primer lugar referirse brevemente a los anuncios de esta entidad financiera para luego compararlos con la viñeta. Se trata de una campaña nacida en junio de 2010 a cargo de la agencia Sra Rushmore, constituida por diversos vídeos, en los que personas retractadas en distintas situaciones, se dividen en dos categorías fundamentales: «ahorrador/no-ahorrador». Obviamente el pertenecer a una u otra categoría depende de si se cuenta o no con los servicios del banco promocionado. El concepto es claro, pues, si tienes una cuenta ING Direct eres ahorrador, si no eres un no ahorrador. Las personas de los vídeos aparecen definidas con un pie sobreimpreso «ahorrador»o «no ahorrador», exactamente como el que define los personajes de la viñeta abajo. En la viñeta los transeúntes también se distinguen entre ahorradores y no ahorradores, pero

23 En efecto me parece reductivo considerarlo un simple ejemplo de antonomasia (v. observaciones conclusivas). 
hay uno, cuyas facciones corresponden a las facciones caricaturizadas del Presidente del Gobierno, que es definido «endeudador». Fíjense en el uso del color rojo en el pie correspondiente a Zapatero en la viñeta. Resalta la diferencia de la persona indicada con los demás transeúntes, pero además indica el color ideológico del personaje: rojo $=$ zapatero $=$ PSOE $=$ socialista .

Fig. 5 Zapatero endeudador. ABC, viernes 11 de febrero de 2011, p. 14.

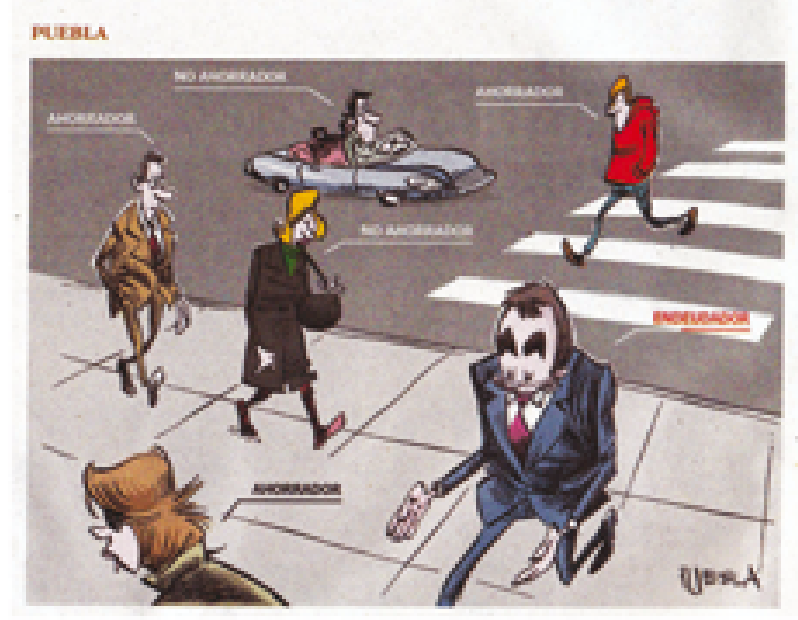

Sin el conocimiento previo del anuncio por parte de los receptores la viñeta conseguiría ciertamente el objetivo de definir al Presidente del Gobierno de la forma como pretenden hacerlo Puebla y ABC (y el PP), pero sin los poderosos efectos mnemónicos que tiene por el hecho de referirse, parodiándolo, a un anuncio de la TV. La parodia incrementa los efectos persuasivos gracias también al hecho de suscitar hilaridad. Es un ejemplo de persuasión emotivo-afectiva. Se trata de un uso de la publicidad para "hacer política": un sujeto político explota una publicidad (dándola por sobradamente conocida), sus palabras y sus categorías, para poder enviar su mensaje político.

\subsubsection{La campaña electoral del Partido Comunista Italiano en 1953}

Como intentaré demostrar en este párrafo, la relación entre la publicidad y la política es más profunda, estrecha y sobre todo antigua de lo que podría parecer a primera vista. En cierto sentido estos dos discursos siempre han estado íntimamente ligados por sus analogías funcionales (compeler el receptor a tomar decisiones de compra o de voto) y discursivas (son textos persuasivos y retóricos).

El Partido Comunista Italiano (PCI) ya en 1953 usó una referencia a una publicidad muy conocida en aquella época: el anuncio del licor Cynar. Cabe aquí introducir brevemente algún dato sobre esta bebida, para luego analizar someramente el anuncio del 
PCI. En 1949 la empresa Pezziol lanzó una bebida de aguardiente aromatizada a la alcachofa. Ya en 1951 las ventas habían superado el millón de botellas, alcanzando el licor un éxito notable ${ }^{24}$. Con el producto también se difundió el eslogan con el que la marca comercializaba su licor: «contro il logorio della vita moderna» [contra el agotamiento de la vida moderna], se sobreentiende el imperativo «bevete Cynar» [bebed Cynar]. En 1953, en plena campaña electoral legislativa, aparece este cartel electoral del PCI. Se puede suponer que por aquel entonces tanto Cynar como su eslogan, eran muy conocidos, pues de lo contrario el discurso del PCI no habría tenido ninguna fuerza persuasiva. Abajo (Fig. 6) se compara el anuncio del PCI con otros dos anuncios de la marca, con la frase que -ejemplo de longevidad comunicativa- ha sido y sigue siendo el eslogan de la marca.

Fig. 6 Dos anuncios de Cynar y el cartel del PCI
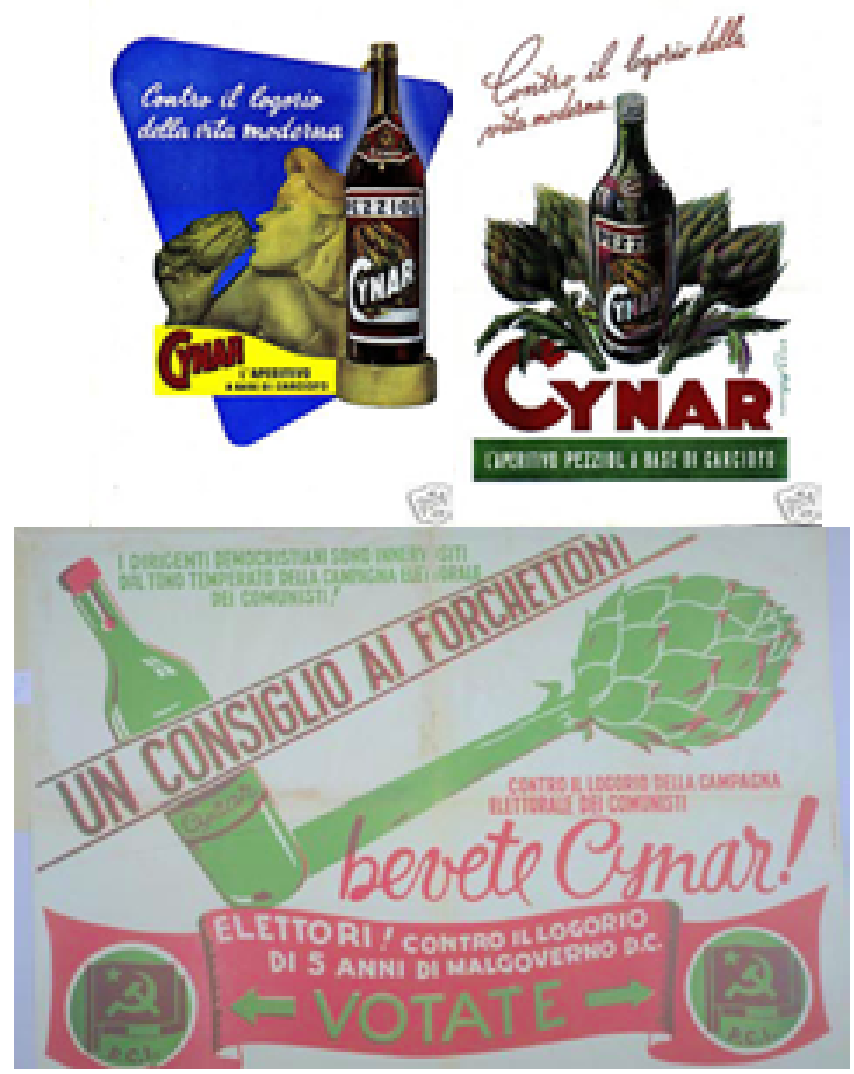

24 La marca Cynar ha sido propiedad de la empresa paduana Pezziol hasta que, tras pasar por manos holandesas, llegó a la italiana Campari, actual propietaria, en 1995. JONES, A. (1998): Aperitivi, Rimini, Idea Libri. 
Es preciso hacer algunas aclaraciones: 1) el Cynar es un licor digestivo; 2) a partir de 1951 en adelante los democristianos (representantes y electores del partido de la DC Democrazia Crisitiana) eran definidos forchettoni, literalmente «grandes tenedores», del italiano forchetta, «tenedon», esto es, «comilones», «glotones». El término indicaba despectivamente a los democristianos connotándolos como gente interesada solo en la satisfacción de sus intereses personales, reunidos bajo la referencia metafórica a la comida. He aquí la transcripción (según el sentido de lectura, de izquierda a derecha y de arriba abajo) del cartel electoral del PCI: «i dirigenti democristiani sono innervositi dal tono temperato della campagna elettorale dei comunisti. Un consiglio ai forchettoni. Contro il logorio della campagna elettorale dei comunisti bevete Cynar! Elettori! Contro il logorio di 5 anni di malgoverno DC votate $\mathrm{PCI}^{25}$ ». Está clarísimo el paralelo entre las virtudes del licor por resolver problemas digestivos y las virtudes del PCI por resolver los problemas causados por la DC. Es interesante notar que el mensaje es doble, pues se dirige a los oponentes y a los electores. Las virtudes del Cynar pueden curar a los oponentes, quienes estarían agotados por curar demasiado sus intereses, esto es, metafóricamente, por comer demasiado. Pero las virtudes digestivas del Cynar pueden curar a los oponentes también de la campaña electoral de los comunistas, especialmente difícil de "digerir" para los DC. Paralelamente el PCI puede curar a los electores del mal gobierno de la DC. Las referencias al licor son explícitas, a nivel visual (botella con marca, alcachofa) y verbal (nombre del licor). Pese a la argumentación especialmente farragosa y larga para un anuncio el mensaje del cartel es claro: el PCI cura tanto como el Cynar. Pero aquí lo interesante es notar: 1) que los discursos son «discursos de discursos», de hecho aquí un discurso público (político) retoma otro discurso público (comercial), lo cita abiertamente y lo plantea como presupuesto lógico para su argumentación, como elemento cultural compartido con el receptor; 2) que ya en 1953 un partido político se sirve del anuncio de una marca comercial y de su eslogan para promocionarse y persuadir al electorado; 3 ) que sea un partido comunista y por tanto opositor del capitalismo y del comercio a (re)tomar discursos comerciales.

\subsection{La publicidad usa la política}

Pasemos ahora a analizar tres casos en los que la publicidad toma prestados estructuras, lenguajes, formas, términos, nombres y personajes a la política. En el primer apartado se analizará el anuncio de la cerveza argentina Quilmes, en el segundo, el anuncio de los desodorantes Axe, y en el tercero el anuncio de los caramelos M\&M's.

25 Traducción (del autor): «los dirigentes democristianos están enfadados por el tono moderado de la campaña electoral de los comunistas. Un consejo a los comilones, contra el agotamiento por la campaña electoral de los comunistas, ¡bebed Cynar! ¡Electores! Contra el agotamiento por 5 años de mal gobierno democristiano, votad PCI». 


\subsubsection{El anuncio de Quilmes}

El vídeo analizado aquí es el anuncio llamado «Partido de la $\operatorname{costa}^{26} »$, de la agencia Young \& Rubicam, estrenado en diciembre de 2006, de cara al verano austral de 2007. En él, una foca da un discurso desde un atril adornado con un caballito de mar, situado en una playa con un escenario de cartón (fig. 7). El discurso de la foca es una parodia de un discurso político. A continuación se presenta la transcripción del anuncio. A cada enunciado - marcado aquí con un número arábigo- corresponde una escena que representa cómicamente el contenido del enunciado. El vídeo se abre [0] con un cartel a toda pantalla «2007 año de elecciones» y se cierra [32] con el logotipo de Quilmes.

Fig. 7 Captura del comienzo del spot de Quilmes «Partido de la Costa»

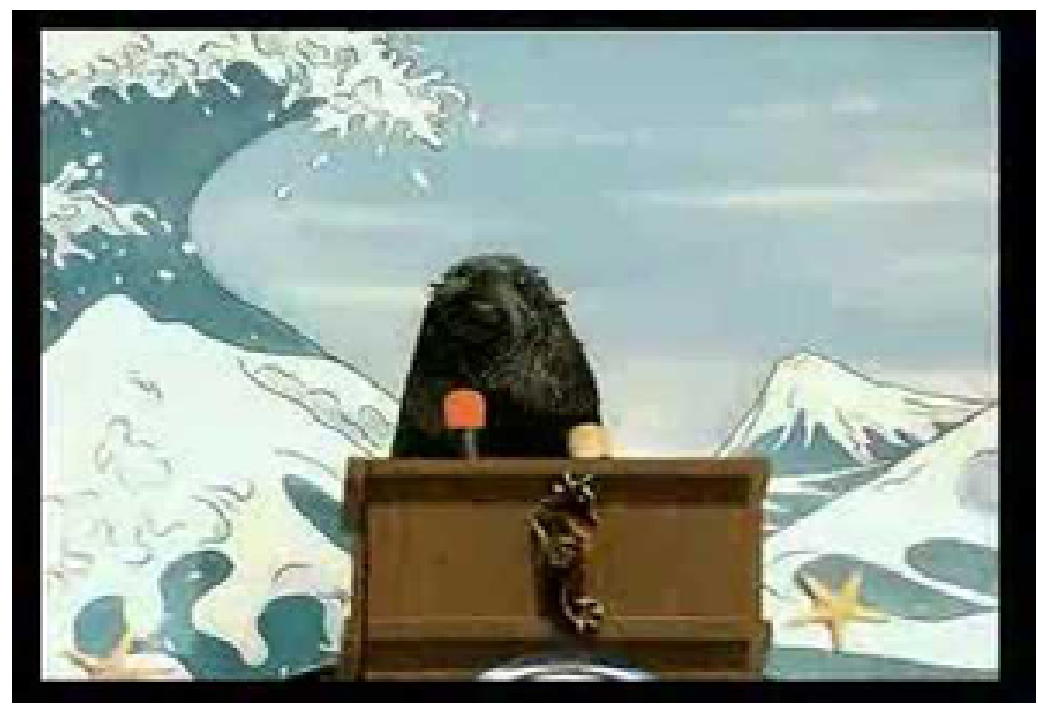

0) [texto: 2007 año de elecciones]

1) Compañeros, compañeras:

2) Estamos aquí reunidos para presentarles un nuevo partido político:

3) El partido de la costa

4) Este partido somos todos, y vos también!

5) Somos un movimiento que va de costa a costa:

6) La costa atlántica, la costa de Miami, la Costanera y el Beto Acosta.

7) Una agrupación que propone:

8) NO al pareo!

9) SI a perderle el miedo a la zunga \{calzoncillo de baño tipo slip, n.d.a.\}!

10) NO a la arena en el auto!

26 Disponible en el siguiente enlace: http://www.youtube.com/watch?v=IOrPuZy9wIw 
11) y NO a la arena en la casa!

12) SI al alquiler de carpa libre de vecinos!

13) SI a viajar en colectivos vacíos en verano!

14) SI al amigo de un amigo de un amigo para dividir gastos!

15) NO a esa nube!

16) SI al caracolote!

17) al que pidió vacaciones en enero, le daremos enero!

18) SI a la banana que tantas alegrías nos dio!

19) SI a las amistades nuevas de verano!

20) SI a la industria nacional!

21) y SI al caracol con jopo!

22) SI al fluo \{color fluorescente, n.d.a.\}!

23) y también NO al fluo! [texto: contradicción interna del partido]

24) SI a la típica modelito de los comerciales de cerveza!

25) porque el pasito de verano sea más fácil para todos!

26) por un baile más justo!

27) por un baile más digno!

28) queremos mover la pelvis!

29) 5, 6, 7 VAAA!

30) VAMOS POR UNA QUILMES! Y POR UN VERANO MEJOR!

31) Un barman a la derecha, gracias.

32) [texto: Quilmes]

No vamos a ahondar aquí en las consideraciones sobre el valor de los elementos culturales (citados o parodiados) que hacen este anuncio divertido y exitoso, como son por ejemplo, la autorreferencialidad [24], las imágenes divertidas de rasgos culturales considerados típicamente argentinos (el fútbol, mediante referencia al jugador Beto Acosta), o kitsch (los suvenires), las referencias a tópicos veraniegos (la arena en los sitios donde menos se la desea; el baile de verano; las prendas veraniegas como el pareo y la zunga), etc.

Lo que aquí interesa es ver que este anuncio emplea términos (compañeros [1], partido [2, 3, 4, 23], movimiento [5], agrupación [7]) y técnicas de la política, lo que la retórica clásica denomina peroratio. Se emplean estructuras y figuras retóricas como las listas (acumulación y anáfora), muy típicas del discurso político. Se emplean eslóganes, aquí con forma de « $\left\langle\mathrm{SI} / \mathrm{NO}+\mathrm{a}(1) / \mathrm{a}\right.$ la + sustantivo», mutuados del discurso político ${ }^{27}$. Se emplea una alocución directa al destinatario [4], un rasgo común al discurso político y al publicitario, pero sobre todo se emplea la primera persona plural inclusiva $[2,4,5,17,18$, $28,30]$, muy típica del discurso político ${ }^{28}$. Aunque sea un animal, el tono del protagonista (actio) y el tenor de su enunciación son típicos del discurso político. Como también lo

Hay muchísimos ejemplos: NO al racismo; NO al aborto, etc.

De entre los muchísimos ejemplos, v. WILSON, J. (1990): op. cit., cap.3.
} 
son la polarización y la división maniquea (SI/NO). También la colocación de los argumentos según un clímax (dispositio), subrayada por la música in crescendo, parece la de un mitin político. Se emplean categorías (contradicción interna del partido [23], justo [26], digno [27]) del registro y del dominio de la política ${ }^{29}$. Sin olvidar que hay dos referencias explícitas a la política argentina, situadas en dos puntos estratégicos de todo texto, la apertura y el cierre. La primera referencia [0], 2007 año de elecciones, alude al hecho de que en Argentina en 2007 han tenido lugar elecciones presidenciales y legislativas ${ }^{30}$. La segunda [31], un barman a la derecha, es un guiño a un famoso discurso del presidente argentino Raúl Alfonsín ${ }^{31}$.

El mensaje es bastante claro: el anuncio pretende mostrar la conexión entre el verano y Quilmes, por encima de las divisiones y los gustos -incluso políticos- de los argentinos. El mitin del partido político se configura así como una excusa. Una especie de escenario donde representar de forma divertida la conexión entre Quilmes y el verano. De ahí que el orador sea un animal. Nada es serio. Todo está dirigido a suscitar simpatía: la foca es un animal tierno, las escenas son divertidas, etc. Pero hay que decir que el mitin es un mecanismo estratégico fundamental para atraer la atención. No sólo por los elementos paródicos, que son siempre eficaces en cuanto suscitan hilaridad, sino porque el hecho de que 2007 sea un año de elecciones vuelve saliente lo que concierne la política, los mítines, el discurso político, etc. De este modo el anuncio se vuelve más saliente y es recibido y memorizado como más importante por los receptores.

El siguiente apartado también concierne el uso de la política, en este caso de una persona-personaje, para promocionar un producto.

\subsubsection{El anuncio de AXE}

Analizaré aquí el anuncio de una conocida marca de desodorantes masculinos, Axe, de la multinacional holandesa Unilever. En este caso el uso de la política (o cuando menos de un conocimiento de la actualidad política) es estratégico. El anuncio se inscribe dentro del concepto general de las últimas campañas de la marca: el poder de Axe de atraer a las mujeres. Este poder es tan notorio que se le define única y sencillamente como «efecto Axe». Para que se tenga una idea del concepto, presento aquí (Fig. 8) otros tres anuncios de la marca, que dejan bastante claro el mensaje: un enchufe, un lápiz, un tornillo (representantes metafóricos del hombre) atraen respectivamente a unas tomas, a unos sacapuntas, y a unas tuercas (representantes metafóricos de las mujeres).

29 Especialmente si consideramos eslóganes [26, 27] con la forma «por + un + sustantivo + (más) + adjetivo», que recuerdan a eslóganes políticos como «por un mundo (más) justo», «por un trabajo (más) digno», etc.

30 Los comicios se celebraron el 28 de octubre de 2007 y fueron ganados por Cristina Fernández de Kirchner.

31 El 17 de abril de 1987, tras un discurso afervorado del entonces presidente Raúl Alfonsín, una mujer del auditorio se desfalleció; Alfonsín la vio y desde el atril pidió un médico para que la socorriera. 
Fig. 8 Tres anuncios de Axe. El concepto de la marca: el efecto de atraer a las mujeres
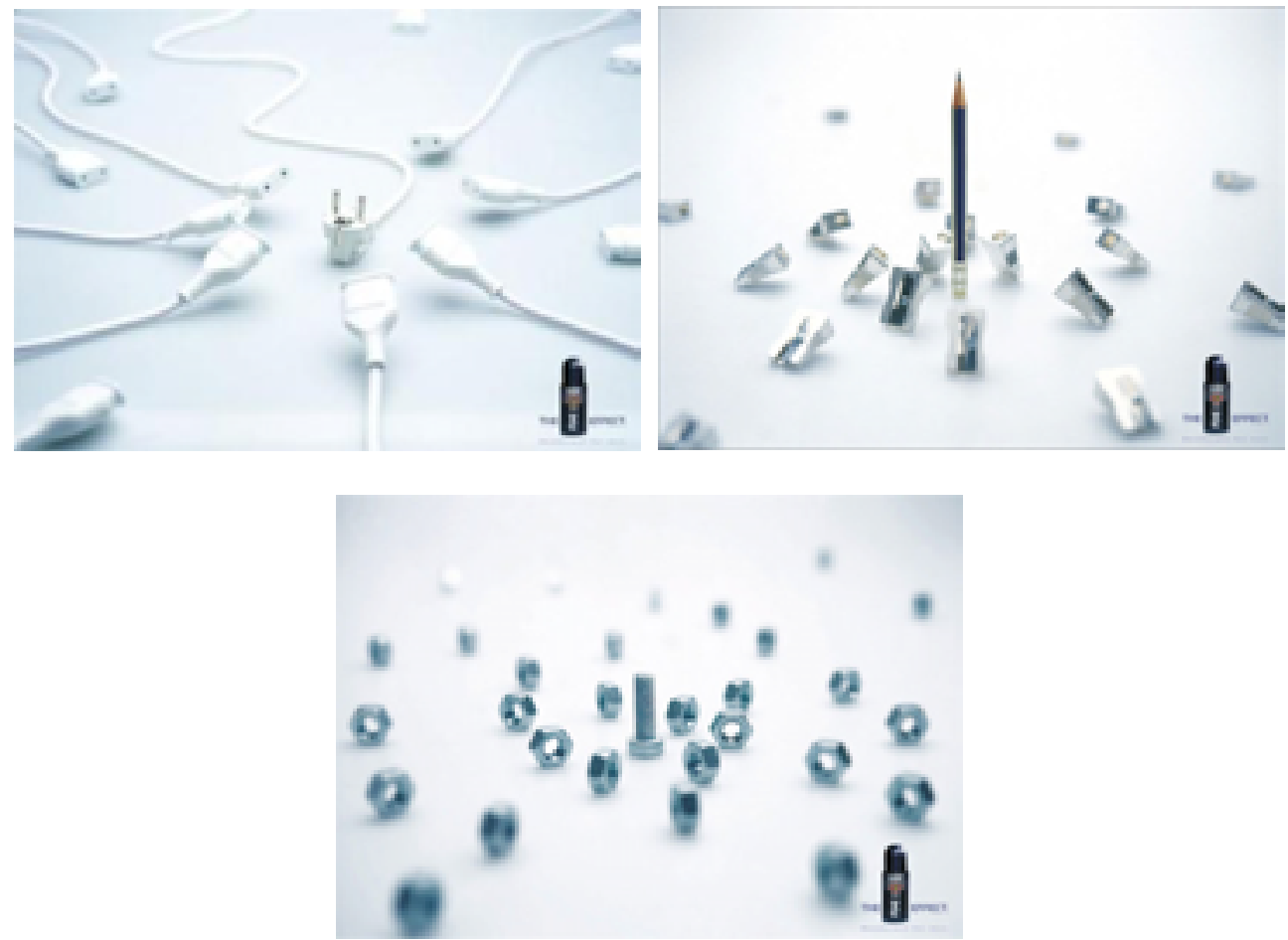

En el caso que nos ocupa, se trata del poder de Barack Obama por atraer a Hillary Clinton, candidata del Partido Demócrata a las primarias contra el mismo Barack Obama $^{32}$. Si se observa bien la foto (Fig. 9), se puede notar que la candidata demócrata luce en su americana una chapa con el nombre de Obama. El efecto del desodorante es tal que Hillary Clinton llega a sostener su oponente, no sabemos si después de haber perdido las elecciones primarias o si simplemente tras haber renunciado a ellas en favor del contrincante. Sea como fuere, el anuncio deja imaginar a los receptores -pues este es el razonamiento al que el emisor los induce, para que «llenen el hueco» que ha dejado en la narración- que la conversión de Hillary Clinton se debe al poder del desodorante usado por el otro candidato demócrata.

32 Como es bien sabido Barack Obama derrotó a Hillary Clinton en las elecciones primarias del Partido Democrático y sucesivamente derrotó al candidato del Partido Republicano John Mc Cain en las elecciones presidenciales americanas. 
Fig. 9 La candidata Hillary Clinton apoyando a Barack Obama

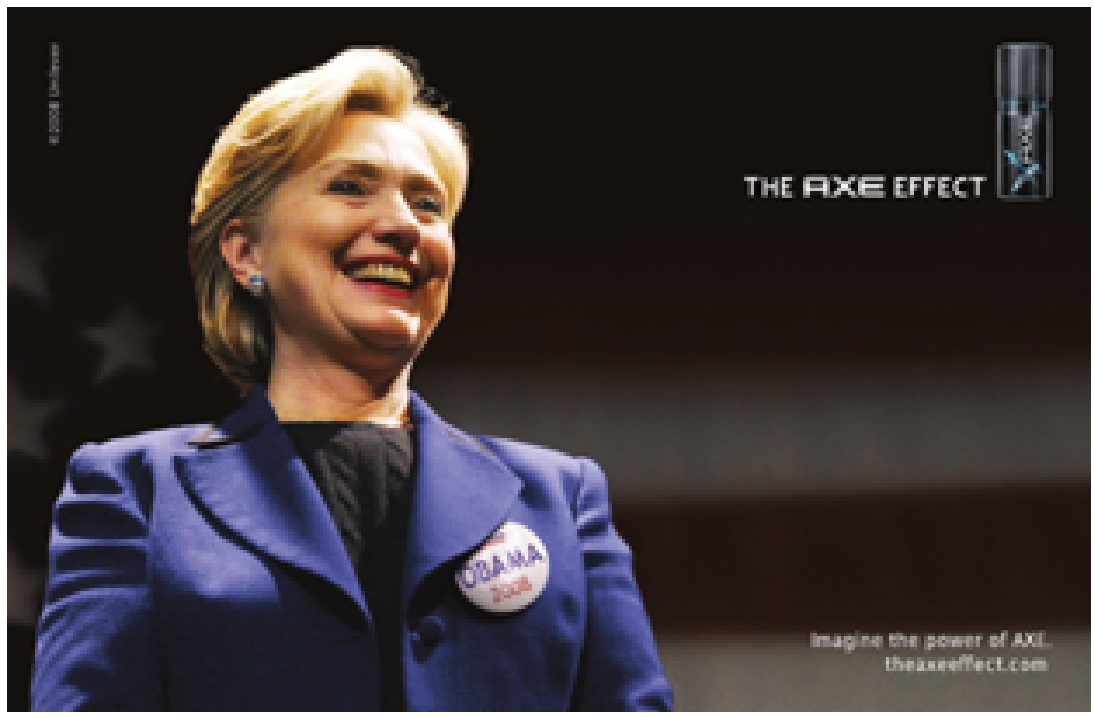

Aquí el mensaje sobre el poder de Axe se ve potenciado por la salience (notabilidad) que tienen los personajes mostrados (Hillary Clinton) o referidos (Obama), especialmente en un año, 2008, en el que se celebran elecciones seguidas y analizadas mundialmente, como son las primarias y presidenciales estadounidenses. En este anuncio la publicidad se sirve del conocimiento básico de la actualidad política en el receptor, para que funcione como presupuesto cultural y discursivo. Sin él, de hecho, el anuncio no podría funcionar.

El caso del apartado siguiente es aún distinto y me parece que merece ser analizado por su originalidad y complejidad.

\subsubsection{El anuncio de M\&M’s}

Este es otro ejemplo de cómo la publicidad aproveche la política y su funcionamiento, su discurso o sus técnicas para promocionar productos. Se trata de una campaña de la marca de chocolatinas M\&M's (Mars and Murrie), perteneciente a la multinacional Mars ${ }^{33}$. La campaña, llamada «M\&Ms Election Campaign», es australiana y data de 2008; transmitida en Australia y Nueva Zelanda, fue desarrollada por Clemenger BBDO en Melbourne. Como se puede ver (Fig. 10), la campaña estaba pensada como un concurso en el que la gente, no por fuerza consumidores de M\&M's, podía votar para su pieza favorita, según el color: «red» [rojo], «green» [verde], «yellow» [amarillo], «crispy» [marrón], y «blue» [azul].

33 Los M\&M's son unas pequeñas chocolatinas recubiertas de azúcar glasé de distintos colores: marón, verde, azul, amarillo y rojo. 
Fig. 10 La campaña publicitaria M\&M's Election
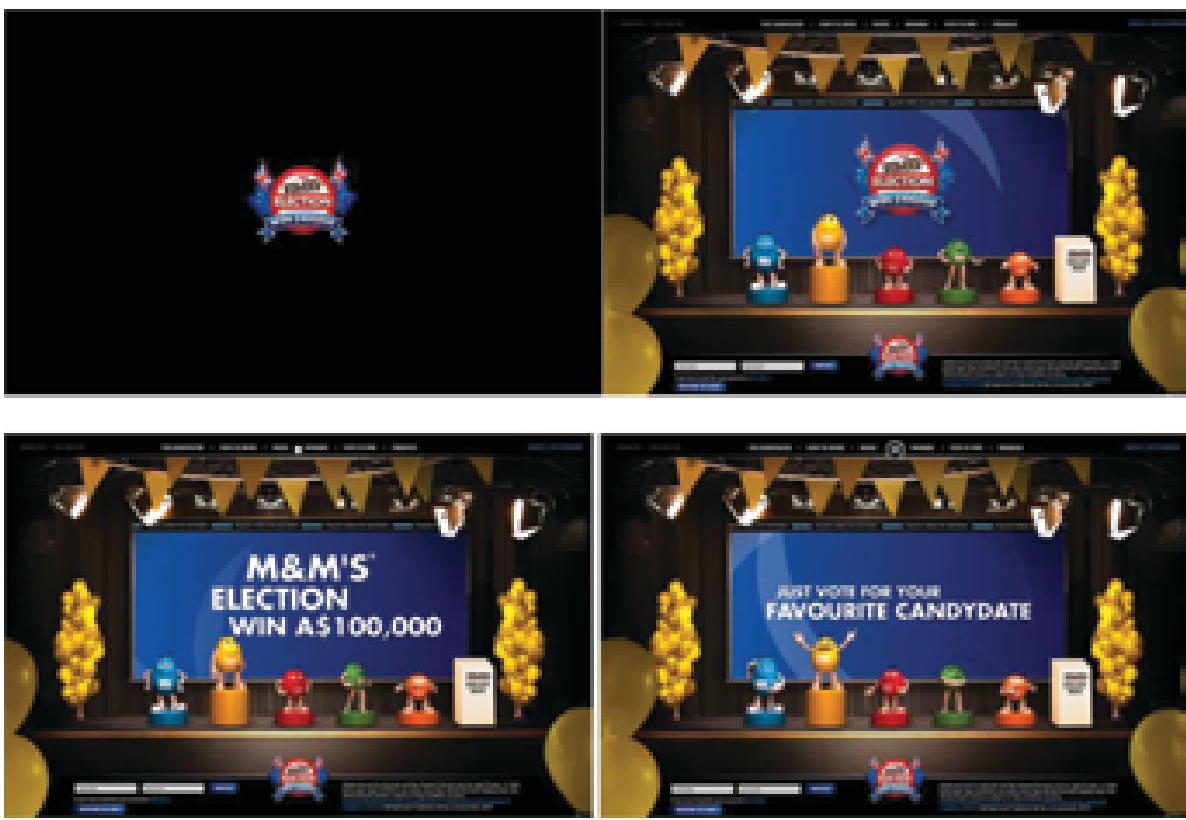

Las diferentes piezas se presentaban así como cinco candidatos. Nótese que productos como los M\&M's se llaman en inglés candy y que la palabra inglesa candidate (candidato) permite un juego de palabra: candydate (Fig. 10). Cada uno de los candidatos se presentaba con el número uno, de acuerdo con el sistema electoral australiano, basado sobre las preferencias. Cada candidato tenía una personalidad y un estilo discursivo propios.

Cada candidato tenía un poster con su propio eslogan (Fig. 11) y contaba con un vídeo (televisado y disponible en la web) de 5 segundos en el que hacía un breve discurso que concluía con su eslogan. En fin, los caramelos estaban representados como verdaderos candidatos políticos. Para que la gente votase, estas peculiares elecciones habían sido pensadas como un concurso con premios semanales por un total de 100.000 dólares australianos (unos 74.000 €) (Fig. 10). Los eslóganes de los personajes eran los siguientes: «The Redolution ${ }^{34}$ is Now. Vote Red!»; «Vote 1 Yellow. The People's Candy-Date»; «A Vote for Blue is a vote for you»; «Vote 1 Crispy. Carrying the nerves of a nation»; «Vote 1 Green. Miss Green Working the Polls». La campaña tenía su soporte principal en la web, de la que reproducimos abajo algunas impresiones de pantalla (Fig. 12). Es importante notar que toda la campaña estaba pensada como una elección: en la página web de M\&M's se podía ver el vídeo de cada candidato, una ficha breve con sus indicaciones personales principales, su poster, la situación de los

34 Juego de palabra entre red (rojo) y revolution (revolución). Obviamente el rojo estaba caracterizado como el más rebelde y agresivo y con una estética maoísta o soviética. 
respectivos candidatos con respecto a los demás en cada uno de los estados australianos o neozelandeses, como tras encuestas a pié de urna, y, obviamente, se podía expresar el voto, marcando la papeleta virtual y depositándola en la urna virtual ${ }^{35}$, reproducida abajo (Fig. 13).

Fig. 11 Los cinco candidatos de M\&M’s Election Campaign
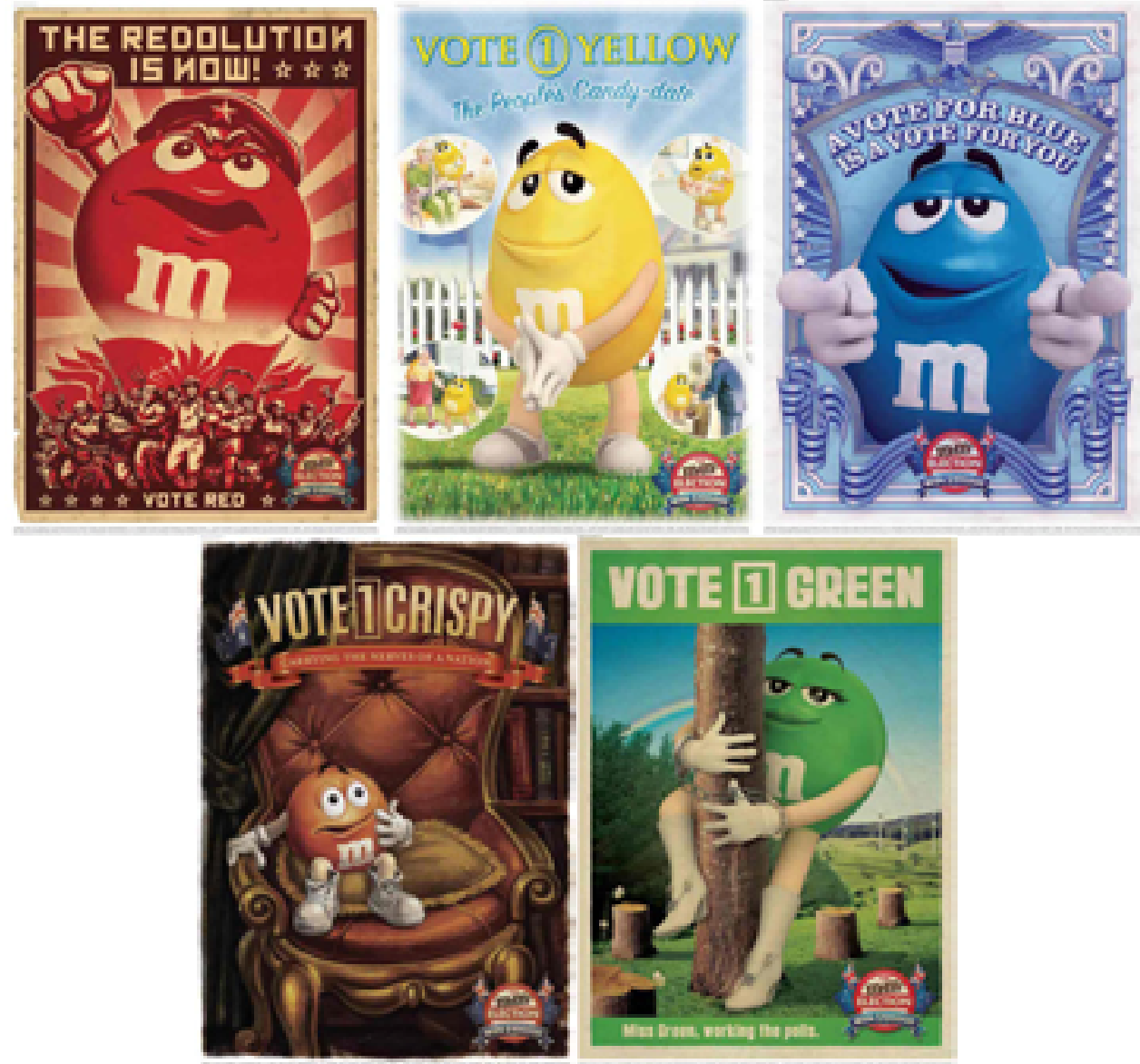

$35 \mathrm{Al}$ momento el proceso de votación ya ha acabado. ¡Ganó el amarillo! (Fig. 8). 
Fig. 12 Los espacios virtuales como espacios políticos
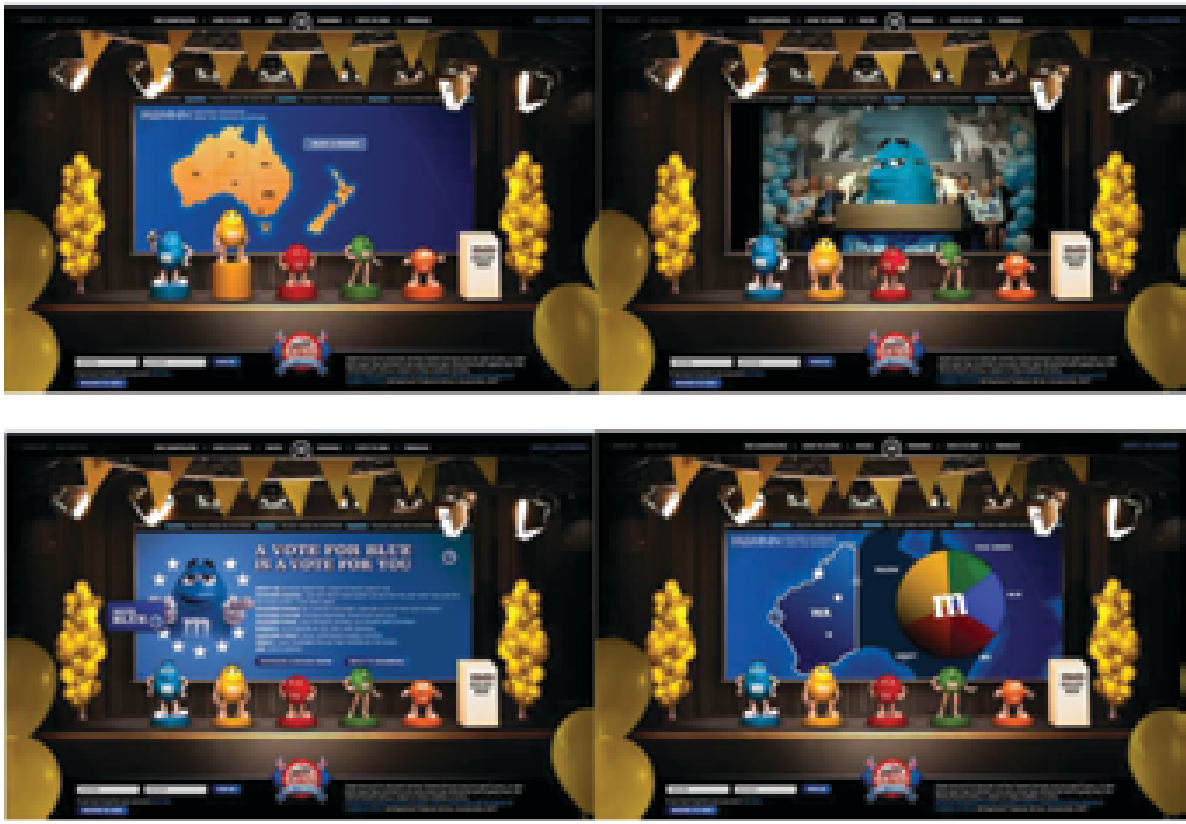

Fig. 13 La papeleta y la urna

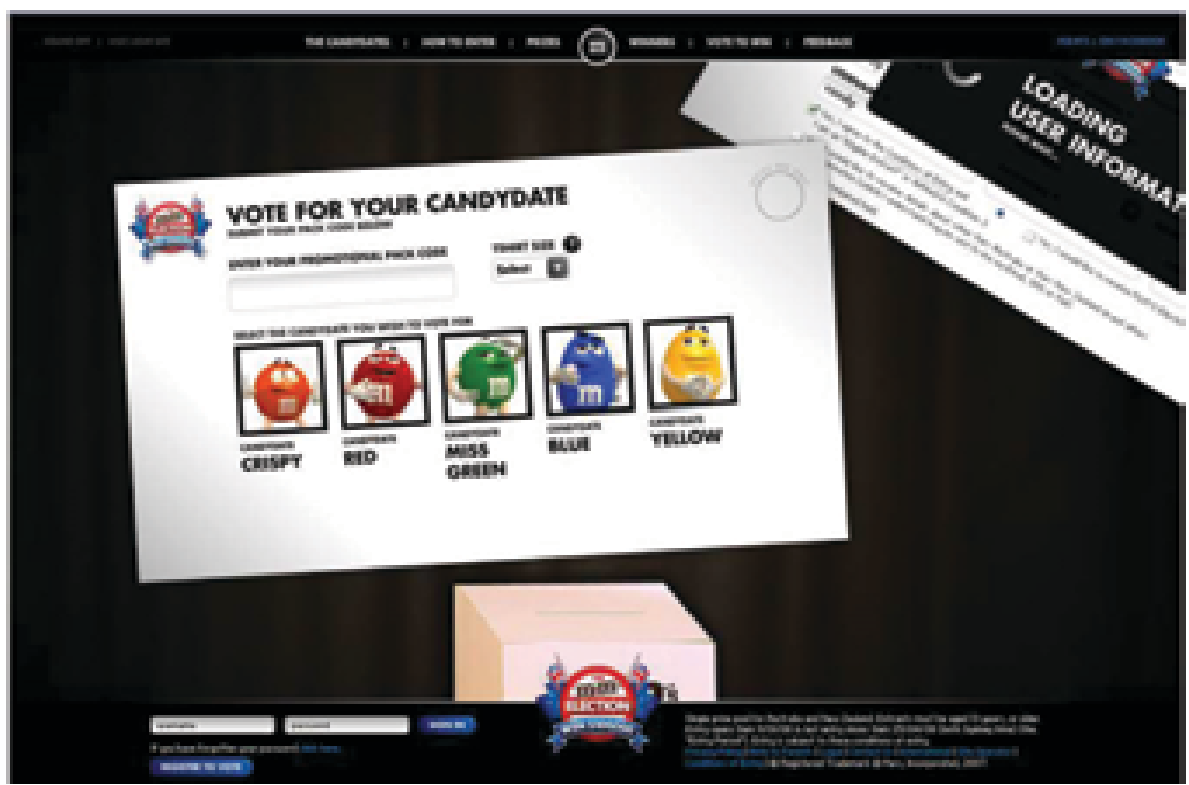


No cabe aquí ahondar en los aspectos que hacen de este anuncio, como se puede notar, un claro y extremadamente original ejemplo de aprovechamiento del discurso político por parte de la publicidad. Se emplean palabras de la política, sus gestos, su(s) discurso(s), los elementos contextuales del dominio de la política, como la competición electoral -máxima expresión del mundo político- y sus formas, sus características estructurales y formales, pero también elementos secundarios como la pantalla detrás de los candidatos, el logotipo imitando el de la emisora CNN, los gráficos de colores, el espacio preparado como para una fiesta de partido con globos y pancartas, los atriles de los candidatos, sus expresiones, sus eslóganes, etc. Todo parece prestado a la política. El anuncio establece el mundo político (con sus comicios, vídeos, posters, mítines, encuestas, gráficos, eslóganes, etc.) como presupuesto cultural para garantizar la persuasividad de la comunicación comercial.

Pero a la vez escenificar el anuncio como un proceso electoral no deja de ser una parodia del mundo político y de su(s) discurso(s).

\section{Análisis}

Mientras que en el primer caso (campaña publicitaria de Zapatero), el emisor (político), el PSOE, emplea técnicas de la publicidad (logotipos) para fines políticos (hacer votar al candidato), en el segundo ejemplo (Zapatero endeudador) el emisor (político), $\mathrm{ABC}$, emplea la publicidad citándola (anuncio de ING Direct) para un fin político (desacreditar al Presidente del Gobierno y su política). Utiliza la publicidad como marco de referencia cultural, considerando el anuncio un elemento conocido (given knowledge) y compartido con el receptor, esto es, dando por sentado que todos los receptores conocen la publicidad en cuestión. Lo mismo ocurre en el tercer caso, donde el emisor (político), el PCI, desacredita al partido rival y se acredita a sí mismo mediante una referencia a un anuncio (Cynar).

Lo mismo parece ocurrir en los tres casos en los que la publicidad toma a la política como referencia para incrementar su portada. Los primeros dos ejemplos son un tanto peculiares: su capacidad de persuasión se ve incrementada mediante un aumento a nivel cognitivo de su notabilidad informativa (salience), de su importancia con respecto al contexto ${ }^{36}$. Si se observan el anuncio de Quilmes y el de Axe, se verá que en realidad no se trata de anuncios que «hacen política», sino que simplemente toman prestados algunos elementos del ámbito político, pero para aprovecharlos de forma contingente. Es decir, la publicidad aprovecha la contingencia política (las elecciones en Argentina o en USA) para dotar de más resonancia y peso persuasivo sus anuncios. Se aprovecha la coyuntura política para dotar de más notabilidad a los anuncios, lo que, en última instancia les confiere más interés y más probabilidades de ser recordado, y en

36 El de salience es un concepto mutuado de la teoría de la psicología social, que tiene origen en la psicología de la Gestalt, v. Hewston ET AL. (1998): op. cit. 
consecuencia más probabilidades de obtener los fines comerciales por los que nacieron. En efecto el anuncio de Quilmes cita al principio y al final ${ }^{37}$ la política para situarse en un contexto y así ganar notabilidad informativa en el flujo de mensajes persuasivos (políticos o publicitarios). Lo mismo hace Axe, quien aprovecha la mediatización de los personajes Clinton y Obama para contextualizar su discurso sobre unos acontecimientos políticos que en ese momento eran muy notables. Distinto es el caso del tercer ejemplo (elecciones de M\&M's), donde no hay coincidencia con las elecciones australianas y donde el hecho de escenificar la campaña publicitaria como una campaña electoral permite involucrar activamente los receptores-electores (quienes para optar al premio deben votar), garantizando así una mayor influencia sobre ellos.

En cambio, una característica que comparten los tres anuncios (Quilmes, Axe y M\&M's) es la parodia, la mofa, el espíritu jocoso. No se ridiculiza explícitamente la política, pero se la vuelve cómica. Se aprovecha la política para hacer reír. Esto tiene efectos seguramente muy provechosos para el producto anunciado, pues los discursos placenteros son recibidos mejor y recordados durante más tiempo. Este espíritu jocoso es ajeno al político ${ }^{38}$. La política toma muy en serio la publicidad, mientras que la publicidad toma muy en broma la política. Si como se ha sostenido desde muchos foros ${ }^{39}$ la política se ha, cuando menos banalizado o «jibarizado» al adoptar técnicas publicitarias y comerciales, qué pensar del hecho de que la publicidad se mofa o parodia la política: ¿cómo no pensar que se trata de una banalización de la política?

\section{Observaciones conclusivas}

He presentado casos de mezclas del discurso publicitario en el político y del discurso político en el publicitario, pero hablar de «préstamos cruzados» entre la política y la publicidad, no debe sugerir una idea equivocada de que las relaciones entre estos dos universos simbólicos y semióticos sean recíprocas, esto es, que los intercambios entre estos dos universos socio-discursivos sean simétricos. La definición de «préstamos cruzados» parece reducir el papel preponderante que juega la publicidad en la sociedad actual a nivel local y global.

Tras el análisis de las páginas precedentes me parece que se pueda destacar críticamente la «tiranía» absoluta de la publicidad (entendida como sistema para vender opciones lato sensu) sobre otros discursos, especialmente sobre el político. El hecho de que los políticos se sirvan de agencias de publicidad para ser elegidos o que las campañas no se jueguen sobre la discusión racional, sino sobre la persuasión emotiva (publi-

37 Aprovechando los llamados efectos de primacy y recency, v. HewSTON ET AL. (1998): op. cit.; PratKANIS, A. y E. ARONSON (1994): op. cit.

38 No se puede confundir el caso de la cita del anuncio de ING Direct por parte de ABC. Ahí se trataba de un género textual, la viñeta satírica, en el que la mofa es esencial.

39 Por ejemplo el proprio CAMPMANY, J. (2005), op. cit., 252-253. 
citaria) o el hecho de que los políticos usen a los anuncios en sus discursos políticos e institucionales lo prueba ampliamente.

Puesto que los discursos expresan filosofias, Weltanschauung o ideologías ${ }^{40}$ diferentes y a menudo en competición ${ }^{41}$, la tiranía del discurso publicitario sobre los demás discursos (como sobre el político) demuestra la tiranía de la ideología capitalista, perfectamente representada por el discurso publicitario, sobre otras ideologías, que son minimizadas, silenciadas o anuladas.

Desde esta perspectiva, el publicitario se configura como un discurso totalizante, a diferencia del discurso político. En efecto, aunque en algunos anuncios aparezcan palabras o personajes de la política, es el discurso publicitario que ha ocupado otros dominios, que ha ganado terrenos socio-discursivos y no viceversa. $\mathrm{Y}$ esto es así porque la perspectiva comercial de producir/comprar/vender, es decir, la ideología mercantilista, ha ganado sobre cualquier otra. Especialmente esta ideología comercial, capitalista, ha ganado sobre la política cuando menos en el sentido de que no existe a nivel parlamentario puesta en duda de su validez, no existe alternativa política al capitalismo, como ideología y como sistema, no existen políticos distintos entre sí, algo que, por cierto, ha favorecido la «comercialización», la marketingización de la política, esto es, la adopción de técnicas publicitarias para vender candidatos a los electores, de la misma manera como se venden productos a los compradores ${ }^{42}$.

Otra cosa que conviene aclarar es que el discurso publicitario es un tipo de discurso ideológico ${ }^{43}$, en cuanto la publicidad (comercial) construye, transmite, sostiene y perpetúa una ideología, una visión del mundo, que es la capitalista. Ciertamente puede ocurrir que el discurso publicitario, el discurso que representa mejor la ideología capitalista (producir/comprar/vender), se exprese con vocablos o estructuras originariamente pertenecientes a otros ámbitos o dominios, que ocupe espacios textuales, espacios semióticos (y sociales) antes ocupados por otros ${ }^{44}$, como ocurre con los anuncios analizados aquí que «toman prestados» temas, formas, palabras, eslóganes, estructuras textuales, personas-personajes de la políticas o que, dando por supuestos el conocimiento de algunos términos políticos (o el funcionamiento del mundo político) los exploten para anunciar su producto. Pero no hay que dejarse engañar. Más que de una simetría de los dos dominios (político y comercial), este fenómeno parece ser un ejemplo más

\footnotetext{
40 Obviamente los dos términos no pueden considerarse sinónimos simplemente y sin alguna dificultad.

Voloshinov, V. (1929): Marxism and the Philosophy of Language, Cambridge (MA), Harvard University Press, 1973; VAN DIJK, T. A. (1999): Ideología. Un enfoque multidisciplinario, Barcelona, Gedisa; VAN DIJK, T. A. (2003): Ideología y discurso, Barcelona, Ariel.

42 REY, J. (1999): op. cit., 20-27.

43 La publicidad no puede considerarse un discurso político, al menos no en el sentido estricto adoptado aquí, pero es sin duda un discurso ideológico, pues construye y expresa ideologías y es socialmente estructurante.

44 Algo que, por cierto ya otros analistas de la publicidad han destacado. Por ejemplo, PIGNOTTI, L. (1976): La super-nada. Ideología y lenguaje de la publicidad, Valencia, Fernando Torres, ha destacado cómo la publicidad utilice la literatura, la poesía, el teatro, etc.
} 
de la capacidad de la publicidad por fagocitarlo todo. Parece ser un ejemplo más de la capacidad del sistema capitalista por ser omnipresente y totalizante en el sentido de que se hace con todo, en este caso con los demás discursos, englobándolos en su interior, para así neutralizarlos ${ }^{45}$. En efecto ese sistema lo toma todo, lo coloniza todo, todos los demás discursos, especialmente aquéllos críticos o de oposición, de manera que al incluirlos en su interior, los digiere y los desactiva. Es por ello que se considera aquí que los préstamos, aunque sean cruzados, entre los dos discursos no tienen el mismo valor, ni son recíprocos, ni simétricos: los préstamos por parte del discurso publicitario de palabras o formas de la política son apropiaciones del espacio político por el comercial, los préstamos por parte del discurso político de palabras y formas de la publicidad son colonizaciones del espacio de la política por parte de la ideología comercial ${ }^{46}$. El hecho de que la publicidad asuma tonos o palabras o formas de la política no es un simple ejemplo más de la interdiscursividad, esto es, del hecho de que existen discursos que se refieren a otros discursos o que citan a otros discursos o que toman como presupuestos a otros discursos ${ }^{47}$. De acuerdo con lo apuntado arriba, el préstamo de palabras de la política por parte de la publicidad y de palabras de la publicidad por parte de la política demuestra, no sólo que «la publicidad está más viva que nunca», para decirlo en los términos de Bermejo ${ }^{48}$, sino que está tan viva que ocupa todos los espacios de la vida social, de la vida cotidiana ${ }^{49}$ como de la vida política. Ya no se puede hacer política sin publicidad. La publicidad es omnipresente y lo fagocita todo ${ }^{50}$. Pero la publici-

45 Marcuse, H. (1968): El hombre unidimensional, Barcelona, Seix Barral; PigNOTTI, L. (1976): op. cit..

46 Como ejemplos de esta tendencia del discurso político a usar palabras y categorías del discurso y de la ideología comercial se puede citar el $A B C$ del jueves 16 de diciembre de 2010, donde se usa tres veces la palabra marca ya sea unida a conceptos políticos, ya sea en el dominio político, ya sea en el discurso de políticos o bien en referencia a políticos: 1) en las palabras del Príncipe Felipe, «la alta velocidad nos da prestigio internacional y potencia la imagen de marca de España» (p.6); 2) el presidente de Andalucía lanza un proyecto para mejorar la imagen de marca de Andalucía (p.7); 3) el periodista Ignacio Camacho considera que Zapatero es ya «una marca perdedora» (p.15). Otro ejemplo puede ser el de las palabras de Gonzalo Brujó recogidas en el artículo de Gabriele Cagliani, en el no 2.700 de octubre de 2010, p. 65, de la revista Actualidad Económica, donde se habla de España como de una marca que ha ganado visibilidad internacional tras la victoria en el mundial de fútbol de 2010.

47 Sobre interdiscursividad v. BAUMAN, R. y C. L. BRIGGS (1990): «Poetics and performance as critical perspectives on language and social life», Annual Review of Anthropology, 19, 59-88; BLOMMAERT, J. (2005): Discourse, Cambridge, University Press; SiLVERSTEIN M. y G. URBAN (1996): «The natural history of discourse», en SilversteIn M. y G. URBAn (eds.), Natural History of Discourse, Chicago, University of Chicago Press, 1-17; Foucault, M. (1971): El orden del discurso, Barcelona, Tusquets; VolOSHINOV, V. (1929): op cit.; Albaladejo Mayordomo, T. (2005): «Retórica, Comunicación, Interdiscursividad», Revista de Investigación Lingüística, 3, 28-33.

48 BERMEJO J. (2009): «Editorial: sobre la muerte y resurrección de la publicidad», Pensar la Publicidad, 3(2), 16.

49 GARCía CALDERÓN, C. (2009): «Publicidad y vida cotidiana. La participación de la publicidad en la conformación de la vida cotidiana», Pensar la Publicidad, 3(2).

50 Sobre la intertextualidad en la publicidad v. LÓPEZ MORA, P. (2007): «La intertextualidad como característica esencial del discurso publicitario», CLAC Círculo de Lingüística Aplicada a la Comunicación, 30, 45-67. Sobre la intertextualidad de la publicidad y su "apetito", entendido ya sea como omnivorismo ya 
dad además, también lo banaliza todo, relacionándolo todo con el universo de la producción/compra/venta.

Habrá quien considere el ejemplo de Sarkozy de «limpiar al Kärchen» un simple ejemplo de antonomasia, como en el caso de la palabra Kleenex, nombre de una marca comercial de pañuelos que indica de manera genérica a los pañuelos. El error no está en considerarlo una antonomasia, sino en considerarlo un «simple» caso de ésta. No deja de ser sintomático de la omnipresencia de la publicidad el hecho de que un político use en su discurso público ligado al ejercicio de sus funciones institucionales una metáfora basada sobre un producto comercial. Incluso el fenómeno mismo de la antonomasia por la cual un pañuelo se vuelve «un Kleenex», es sintomático de la capacidad de la publicidad por fagocitar los espacios sociales y discursivos, del discurso común al institucional, como de crear hábitos discursivos, por ejemplo en la nomenclatura. La antonomasia es normal, pues de un hombre guapo se dice que es un Adonis. Lo destacable es que el nombre dado a un objeto (general) sea un nombre comercial (particular). No se puede no ver este tipo de fenómenos como ejemplos de la capacidad de la publicidad por ocupar cada vez más espacios discursivos y sociales, en consecuencia del hecho de que la producción-ventacompra de productos se ha vuelto el elemento realmente básico y estructurante de (la[s] experiencia[s] de) nuestras sociedades contemporáneas.

\section{Referencias bibliográficas}

ADAM J. M. y BONHOMME M. (1997): L'argumentation publicitaire. Rhétorique de l'éloge et de la persuasion, Paris, Armand Colin, 2007.

ALBOUY, S. (1994): Marketing et communication politique, Paris, L'Harmattan.

ARISTÓTELES (1985): Retórica, (ed.) A. TOVAR, Madrid, Centro de Estudios Constitucionales.

Albaladejo MAYORDOMO, T. (1989): Retórica, Madrid, Síntesis.

- (2005): «Retórica, Comunicación, Interdiscursividad», Revista de Investigación Lingüistica, 3 (8), 7-33.

BAUMAN, R. y C. L. BRIGGS (1990): «Poetics and performance as critical perspectives on language and social life», Annual Review of Anthropology, 19, 59-88.

BERMEJO, J. (2009): «Editorial: sobre la muerte y resurrección de la publicidad», Pensar la Publicidad, 3(2), 9-16.

BeUCHOT, M. (2004): La semiótica. Teorías del signo y el lenguaje en la historia, México, FCE. Blommaert, J. (2005): Discourse, Cambridge, University Press.

CAMPMANY, J. (2005): El efecto ZP. 1000 días de campaña para llegar a la Moncloa, Barcelona, Planeta.

CAPRETTINI, GP. (1997): Segni, testi, comunicazione. Gli strumenti semiotici, Turín, Utet.

FAIRCLOUGH, N. (2001): «Critical discourse analysis as a method in social scientific research», en WODAK, R. y M. MEYER (eds.) (2001: 122-138).

sea como canibalismo, esto es, su capacidad por fagocitar otros discursos (de géneros diferentes o del mismo género), v. MORENO DE NICOLÁS, S. (2009): «La publicidad omnímoda: interdiscursividad y el discurso publicitario», IV congreso de la cibersociedad; RODRÍGUEZ FERRÁNDIZ, R. (2003): «Publicidad omnívora, publicidad caníbal: el intertexto polémico», I Jornadas de Publicidade e Comunicação. 
FERraZ MartíneZ, A. (1993): El lenguaje de la publicidad, Madrid, Arco Libros.

GARCÍA CALDERÓN, C. (2009): «Publicidad y vida cotidiana. La participación de la publicidad en la conformación de la vida cotidiana», Pensar la Publicidad, 3(2), 176-196.

Hall, S. (2007): Esto significa esto, esto significa aquello. Semiótica: guía de los signos y su significado, Barcelona, Blume.

Hewstone, M., W. Stroebe y G. M. StePhenson (1998): Manuale di psicologia sociale, Bolonia, Il Mulino

JONES, A. (1998): Aperitivi, Rimini, Idea Libri.

LEVInson, S. (1989): Pragmática, Barcelona, Teide.

LÓPEZ MORA, P. (2007): «La intertextualidad como característica esencial del discurso publicitario», CLAC Círculo de Lingüística Aplicada a la Comunicación, 30, 45-67.

MARCUSE, H. (1968): El hombre unidimensional, ensayo sobre la ideología de la sociedad industrial avanzada. Barcelona, Seix Barral.

MORENO DE NiCOLÁS, S. (2009): «La publicidad omnímoda: interdiscursividad y el discurso publicitario» IV congreso de la cibersociedad 2009. En

http://www.cibersociedad.net/congres2009/es/coms/la-publicidad-omnimodainterdiscursividad-y-el-discurso-publicitario/851/. Web visitada el 10/01/2011.

MORIN, E. (2005): Introducción al pensamiento complejo. Barcelona, Gedisa.

ORIOL COSTA, P. (2008): «Estrategias de comunicación en una campaña electoral», en ORIOL Costa, P. (comp.), Cómo ganar unas elecciones. Comunicación y movilización en las campañas electorales, Barcelona, Paidós, p. 3-70.

PINEDA CACHERO, A. (2007): «Propaganda y publicidad comercial. Un principio diferenciador», Questiones Publicitarias, 1(12), 107-128.

PETTY, R. y CACIOPPO, J. T. (1986a): «the elaboration likelihood model of persuasion», en L. BERKOWITZ (comp.), Advances in experimental social Psychology (vol. 19), New York, Academic Press, 123-205.

PETTY R. y CACIOPPO, J. T. (1986b): Communication and persuasion; central and peripheral routes to attitude change, New York, Springer-Verlag.

PIGNOTTI, L. (1976): La super-nada. Ideología y lenguaje de la publicidad, Valencia, Fernando Torres.

PRATKANIS, A. y E. ARONSON (1994): La era de la propaganda. Uso y abuso de la persuasión, Barcelona, Paidós.

REY, J. (coord.) (1999): «Comunicación política electoral. Elecciones municipales de Sevilla en 1999», Questiones publicitarias/Monografias, 2. Sevilla, Maecei.

REY, J. (ed.) (2005): Propaganda electoral. Elementos publicitarios y estrategias comunicativas en las elecciones municipales de Sevilla en 2003, Sevilla, Maecei.

RODRÍGUEZ ESCANCIANO, I (2004): «la desarticulación de las estrategias electorales audiovisuales frente a la conmoción del 11-M», Área Abierta, 8.

RodríGUEZ ESCANCIANO, I. y M. HERNÁNDEZ HERRARTE (2010): Lenguaje no verbal. Cómo gestionar una comunicación de éxito, Oleiros, Netbiblio.

RODRÍGUEZ FERRÁNDIZ, R. (2003): «Publicidad omnívora, publicidad caníbal: el intertexto polémico», I Jornadas de Publicidade e Comunicação, Universidade da Beira Interior (Covilha, Portugal)-LabCom. En

http://www.labcom.ubi.pt/jornadas_pubcomunicacao/COVILHA-WEB.pdf. Web visitada el 10/01/2011. 
SCRETI, F. (2009), «"Con ceta de zetapero": análisis semiótico de la imagen de marca de José Luis Rodríguez Zapatero para las elecciones generales españolas del 09 de marzo de 2008», Pensar la Publicidad, 3(2), 49-72.

- (2011), «El ojo y la zeta: la propaganda electoral de José Luis Rodríguez Zapatero para las elecciones generales españolas de 2008», Cultura, Lenguaje y Representación, 9, 199-224.

SILVERSTEIN M. y G. URBAN (1996): "The natural history of discourse», en SILVERSTEIN M. y G. URBAN (eds.), Natural History of Discourse, Chicago, University of Chicago Press, 1-17. VAN DIJK, T. A. (1999): Ideología. Un enfoque multidisciplinario, Barcelona, Gedisa.

- (2001): «Multidisciplinary CDA: a plea for diversity», en WODAK, R.; M. MEYER (eds.) (2001: 95-120).

- (2003): Ideología y discurso, Barcelona, Ariel.

VOLOSHINOV, V. (1929): Marxism and the Philosophy of Language, Cambridge (MA), Harvard University Press, 1973.

WILSON, J. (1990): Politically speaking. The pragmatic Analysis of Political Language, Oxford. Blackwell.

WODAK, R. y M. MEYER (2001): Methods of critical discourse analysis, Londres, SAGE. http://election.m-ms.com.au/ http://www.mars.com/global/index.aspx

http://www.mars.com/global/our-brands.aspx

Recibido: 3 de marzo de 2011

Aceptado: 18 de septiembre 2011 